University of Chicago Law School

Chicago Unbound

Journal Articles

Scholarship

2014

Federalism, Treaty Implementation, and Political Process: Bond v United States

Curtis A. Bradley

Follow this and additional works at: https://chicagounbound.uchicago.edu/journal_articles

Part of the Law Commons 


\section{FEDERALISM, TREATY IMPLEMENTATION, AND POLITICAL PROCESS: BOND V. UNITED STATES}

In Bond v. United States, ${ }^{1}$ the U.S. Supreme Court disallowed the prosecution of a domestic poisoning case under legislation that implements the Convention on the Prohibition of the Development, Production, Stockpiling and Use of Chemical Weapons and on Their Destruction. ${ }^{2}$ In doing so, a majority of the Court declined to address constitutional issues concerning the relationship between the national government's treaty power and the U.S. federal system of government. Instead, the majority resolved the case by applying a presumption that federal statutes do not intrude on traditional areas of state authority, such as the prosecution of local crimes, absent a clear indication that Congress intended that result. This interpretive presumption may have implications for how other treaty-implementing legislation is construed, and also for how such legislation is drafted in the United States in the future.

\section{THE TREATY POWER AND AMERICAN FEDERALISM}

The U.S. Constitution grants broad but not unlimited powers to the national government. The Tenth Amendment to the Constitution expressly reserves some authority to the constituent states, or to the people. ${ }^{3}$ One of the powers granted to the national government is to conclude treaties on behalf of the United States. This power is shared between the executive and legislative branches: the Constitution gives the president the authority to conclude treaties, but it requires that he obtain the advice and consent of two-thirds of the Senate. ${ }^{4}$ Treaties ratified by the United States are part of the supreme law of the land and can be enforced by the courts if they are self-executing. ${ }^{5}$ When there is a conflict between a valid self-executing treaty and state law, the state law is preempted. ${ }^{6}$

The scope of the national government's treaty power has long been debated in the United States. The Constitution specifies the required process for making treaties but does not articulate limits on the content of treaties or the extent to which they can be used to effectuate changes in domestic law. The seminal decision concerning the scope of the treaty power is Missouri v. Holland. ${ }^{7}$ In that case, the state of Missouri sued to prevent a federal game warden

${ }^{1}$ 134S.Cr. 2077 (2014), slip op. available athttp:/www.supremecourt.gov/opinions/13pdf/12-158_6579.pdf.

${ }^{2}$ See 18 U.S.C. $\$ 229$ (2012) (implementing Convention on the Prohibition of the Development, Production, Stockpiling and Use of Chemical Weapons and on Their Destruction, opened for signature Jan. 13, 1993, S. TREATY DOC. NO. 103-21, 1974 UNTS 45 [hereinafter Chemical Weapons Convention]).

${ }^{3}$ U.S. CONST. amend. X ("The powers not delegated to the United States by the Constitution, nor prohibited by it to the States, are reserved to the States respectively, or to the people.").

${ }^{4}$ See U.S. CONST. Art. II, $\$ 2$ (providing that the president "shall have Power, by and with the Advice and Consent of the Senate, to make Treaties, provided two thirds of the Senators present concur").

${ }^{5}$ See U.S. CONST. Art. VI ("[A]ll Treaties made, or which shall be made, under the Authority of the United States, shall be the supreme Law of the Land; and the Judges in every State shall be bound thereby, any Thing in the Constitution or Laws of any State to the Contrary notwithstanding."); see also, e.g., Foster v. Neilson, 27 U.S. (2 Pet.) 253, 254 (1829) (noting that a treaty is "to be regarded in courts of justice as equivalent to an act of the legislature, whenever it operates of itself without the aid of any legislative provision").

${ }^{6}$ See, e.g., Ware v. Hylton, 3 U.S. (3 Dall.) 199, 236 (1796) (Chase, J.) ("A treaty cannot be the Supreme law of the land, that is of all the United States, if any act of a State Legislature can stand in its way."). For additional discussion of the status of treaties in the U.S. legal system, see CURTIS A. BRADLEY, INTERNATIONAL LAW IN THE U.S. LEGAL SYSTEM, ch. 2 (2013).

${ }^{7}$ Missouri v. Holland, 252 U.S. 416 (1920). 
from enforcing the Migratory Bird Treaty Act of 1918, a federal statute that implemented a migratory bird protection treaty concluded between the United States and Great Britain (which at the time was still handling Canada's foreign policy). Two federal district courts had held that an earlier version of the statute, enacted prior to the conclusion of the treaty, was unconstitutional because it infringed on the reserved powers of the states to regulate natural resources within their borders. In Holland, the Court concluded that, regardless of whether those district court decisions were correct, Congress has broader authority when it is implementing a treaty than when it is relying only on its ordinary legislative powers. In upholding the constitutionality of the legislation before it, the Court made clear that it was not implying that there are no limitations on the treaty power, but said that those limitations "must be ascertained in a different way" from the limitations that apply to mere domestic legislation. "No doubt the great body of private relations usually fall within the control of the State," observed the Court, "but a treaty may override its power."

Holland stands for the proposition that the national government has more authority to regulate state and local matters when using the treaty power than when acting pursuant to Congress's domestic legislative authority. ${ }^{10}$ This proposition has sometimes been questioned, most significantly during the Bricker Amendment debates of the 1950s, when the Senate considered (but did not adopt) various proposed constitutional amendments to limit the treaty power. ${ }^{11}$ Even if fully accepted, however, Holland does not settle all issues concerning the scope of the treaty power. Perhaps most notably, it does not settle whether there are subject matter limits on that power. At various times, it has been suggested that the treaty power might be limited to matters of international concern and that it would therefore be improper to use the power to regulate purely domestic matters. ${ }^{12}$ In Holland, the Court did not address this issue directly, but it did emphasize that migratory birds, which travel across state and national boundaries, could be adequately protected "only by national action in concert with that of another

${ }^{8} \mathrm{Id}$. at 433.

9 Id. at 434 .

10 There is a suggestion in Holland that the treaty power might not be subject to any constitutional limitation other than the two-thirds senatorial consent process specified in Article II. See id. at 433 ("Acts of Congress are the supreme law of the land only when made in pursuance of the Constitution, while treaties are declared to be so when made under the authority of the United States. It is open to question whether the authority of the United States means more than the formal acts prescribed to make the convention."). The Supreme Court subsequently made clear, however, that "no agreement with a foreign nation can confer power on the Congress, or on any other branch of Government, which is free from the restraints of the Constitution." Reid v. Covert, 354 U.S. 1, 15 (1957) (plurality opinion).

11 See generally DUANE TANANBAUM, THE BRICKER AMENDMENT CONTROVERSY: A TEST OF EISENHOWER'S POLITICAL LEADERSHIP (1988). For an extensive defense of Holland on historical grounds, see David M. Golove, Treaty-Making and the Nation: The Historical Foundations of the Nationalist Conception of the Treaty Power, 98 MICH. L. REV. 1075 (2000).

${ }^{12}$ See, e.g., RESTATEMENT (SECOND) FOREIGN RELATIONS LAW OF THE UNITED STATES $\$ 117(1)(\mathrm{a}) \& \mathrm{cmt}$. $\mathrm{b}(1965)$ (contending that the treaty power is limited to matters "of international concern" and that treaties "must relate to the external concerns of the nation as distinguished from matters of a purely internal nature"); Treaties and Executive Agreements: Hearings Before a Subcomm. of the S. Comm. on the Judiciary on S.J. Res. 1, 84th Cong. 183 (1955) (statement by Secretary of State John Foster Dulles that a treaty cannot regulate matters "which do not essentially affect the actions of nations in relation to international affairs, but are purely internal"); Statement of Charles Evans Hughes, 23 ASIL PROC. 194, 194-96 (1929) (suggesting that the treaty power might be limited to "matters of international concern" and thus might not allow for the regulation of matters "which normally and appropriately were within the local jurisdictions of the States"). But see RESTATEMENT (THIRD) OF THE FOREIGN RELATIONS LAW OF THE UNITED STATES $\$ 302 \mathrm{cmt}$. c (1987) ("Contrary to what was once suggested, the Constitution does not require that an international agreement deal only with "matters of international concern."). 
power." 13 The decision is therefore not inconsistent with a subject matter limitation on the treaty power.

The condensed and oracular style of the opinion in Holland - a hallmark of its author, the famous Oliver Wendell Holmes Jr.--also invites questions about its implications. For example, the Court stated, without elaboration, that "[i]f the treaty is valid, there can be no dispute about the validity of the statute under Article I, $\$ 8$, as a necessary and proper means to execute the powers of the Government." ${ }^{14}$ The Constitution gives Congress the authority " $[t]$ o make all Laws which shall be necessary and proper for carrying into Execution" both its own powers and "all other Powers vested by this Constitution in the Government of the United States, or in any Department or Officer thereof," 15 and it has long been assumed that Congress can use this Necessary and Proper Clause authority to implement treaties. ${ }^{16}$ Even if this assumption is true, however, it is going too far to suggest, as Holmes cryptically did, that "there can be no dispute" about the validity of an implementing statute. At a minimum, for legislation to constitute necessary and proper implementation of a treaty, it would presumably need to have a rational relationship to what is required by the treaty. ${ }^{17}$ Most likely, Holmes simply meant that in that case if the migratory birds treaty was valid, so was the implementing legislation, since the legislation was closely connected to the requirements of the treaty.

The Court in Holland was also unclear about the extent to which it viewed the treaty power as immune from federalism limitations. It described the question before it as whether the statute in question "is forbidden by some invisible radiation from the general terms of the Tenth Amendment," ${ }^{18}$ a formulation that does not seem to give much weight to federalism considerations in this context. But it also emphasized that the state interest at issue was modest, given that migratory birds are only temporarily within the borders of a state. By contrast, said the Court, "a national interest of very nearly the first magnitude is involved." ${ }^{19}$ This language suggests a weighing of state and federal interests, not a dismissal of federalism considerations.

During the last two decades, the scope of the treaty power has again become a point of controversy. Part of the reason for this development is the proliferation of treaty making in the post-World War II period. At the time of the constitutional founding, the United States was a party to only a handful of treaties, all bilateral. Today, the United States is a party to thousands of treaties, many of which are broad-based multilateral agreements that resemble legislative

13252 U.S. at 435. The district court in Holland had concluded that, because the migratory birds treaty conferred reciprocal benefits on the United States and Canada, its subject matter fell within the treaty power. See Transcript of Record at 13, Missouri v. Holland, 252 U.S 416 (1920) (No. 609).

${ }^{14} 252$ U.S. at 432.

15 U.S. CONST. Art. I, $\$ 8, \mathrm{cl} .18$.

16 See, e.g., Neely v. Henkel, 180 U.S. 109, 121 (1901) (observing that Congress's authority under the Necessary and Proper Clause "includes the power to enact such legislation as is appropriate to give efficacy to any stipulations which it is competent for the President by and with the advice and consent of the Senate to insert in a treaty with a foreign power"). But see Nicholas Quinn Rosenkranz, Executing the Treaty Power, 118 HARV. L. REV. 1867 (2005) (arguing that the Necessary and Proper Clause gives Congress only the power to enact legislation to facilitate the making of treaties, not the implementation of treaties already made).

${ }^{17}$ Cf. United States v. Comstock, 560 U.S. 126, 134 (2010) (interpreting the Necessary and Proper Clause as allowing Congress to enact any legislation "rationally related to the implementation of a constitutionally enumerated power").

${ }^{18} 252$ U.S. at 434.

${ }^{19}$ Id. at 435 . 
codes. ${ }^{20}$ These treaties, moreover, cover a vast range of subject matters that much more frequently intersect with areas traditionally regulated by domestic law. ${ }^{21}$ This intersection is especially apparent with respect to human rights treaties, which regulate how governments, including the U.S. government, interact with their own citizens. Part of the fallout of the Bricker Amendment controversy was that the United States did not begin ratifying any of the major human rights treaties until the late 1980 s, and even today it is not a party to several of them.

The treaty power has also become controversial again because of the Supreme Court's increased attention to federalism limitations on the national government's authority in recent years. For example, the Court has enforced limits on the scope of Congress's authority to regulate interstate commerce and to protect against state and local violations of individual rights. ${ }^{22}$ It has also held that Congress may not "commandeer" state legislative and executive officials to carry out federal programs. ${ }^{23}$ In addition, the Court has held that states have broad sovereign immunity from private lawsuits, and that Congress has only limited authority to override that immunity. ${ }^{24}$ To be sure, Article I, section 8 of the Constitution assigns Congress an extensive array of powers, and the Supreme Court continues to interpret these powers expansively. ${ }^{25}$ But the Court has shown a willingness to enforce at least modest federalism limits on the reach of Congress's authority.

Some of these federalism limitations, such as restrictions on the scope of the Commerce Clause, are specific to grants of authority to Congress and might not have any direct bearing on the scope of the treaty power. On the other hand, if the purpose of these limitations is to preserve a certain balance of federal and state authority, this purpose might be undermined if the national government could overcome these limitations simply by using a process that involves a supermajority of the Senate rather than the full Congress. In any event, some of the other federalism limitations emphasized by the Supreme Court appear to be grounded more in the overall federal structure of the U.S. constitutional system than in the enumerated power limitations on Congress and thus are potentially applicable to the treaty power.

Even when the Supreme Court has not applied federalism considerations to limit the scope of the national government's authority, it has sometimes taken them into account when interpreting the scope of legislation. Indeed, the Supreme Court's modern revival of federalism limitations on congressional authority can be traced to a 1991 decision, Gregory v. Ashcroft, which involved an interpretive use of federalism. ${ }^{26}$ The issue in Gregory was whether the federal Age Discrimination in Employment Act (ADEA) preempted a Missouri constitutional provision

${ }^{20}$ See U.S. DeP'T OF STATE, TREATIES IN FORCE: A LiST OF TREaTiES AND OTHER INTERNATIONAL AGREEMENTS OF THE UNITED STATES IN FORCE ON JANUARY 1, 2013, at http:/www.state.gov/documents/ organization/218912.pdf.

${ }^{21}$ See Curtis A. Bradley, The Treaty Power and American Federalism, 97 MICH. L. REV. 390, 396-99 (1998) (describing this development).

22 See, e.g., United States v. Morrison, 529 U.S. 598 (2000); City of Boerne v. Flores, 521 U.S. 507 (1997); United States v. Lopez, 514 U.S. 549 (1995).

${ }^{23}$ See Printz v. United States, 521 U.S. 898 (1997); New York v. United States, 505 U.S. 144 (1992).

24 See, e.g., Alden v. Maine, 527 U.S. 706 (1999); Seminole Tribe of Fl. v. Florida, 517 U.S. 44 (1996).

${ }^{25}$ See, e.g., Nat'l Fed'n of Indep. Bus. v. Sebelius, 132 S.Ct. 2566 (2012) (upholding individual mandate in Affordable Care Act under Congress's taxing power); Gonzales v. Raich, 545 U.S. 1, 18 (2005) (holding that Congress may regulate even noncommercial local activities if it "concludes that failure to regulate that class of activity would undercut the regulation of the interstate market in that commodity").

${ }^{26}$ Gregory v. Ashcroft, 501 U.S. 452 (1991). 
that set forth a mandatory retirement age for state judges. The Court did not hold that Congress lacked the authority to override the Missouri provision. Instead, the Court elected to construe the ADEA as not having this effect. Because " $[c]$ ongressional interference with this decision of the people of Missouri, defining their constitutional officers, would upset the usual constitutional balance of federal and state powers," the Court said that it would assume that Congress did not intend such interference. ${ }^{27}$ Drawing on a variety of other federalism decisions, the Court said more generally that if Congress wants to alter the usual balance of federal and state authority, it must make its intention to do so clear. This clear statement rule is needed in part, the Court explained, to ensure that state interests are adequately considered in the legislative process. Noting that it had previously "left primarily to the political process the protection of the States against intrusive exercises of Congress' Commerce Clause powers," the Court stated that "we must be absolutely certain that Congress intended such an exercise." 28

\section{BOND V. UNITED STATES}

Against this backdrop, the Supreme Court decided Bond v. United States on June 2, 2014. The Bond case concerned a criminal prosecution under a federal statute that implements the Chemical Weapons Convention. The United States became a party to the convention in 1997 and adopted implementing legislation the following year. ${ }^{29}$ The convention provides that " $[\mathrm{e}]$ ach State Party shall, in accordance with its constitutional processes, adopt the necessary measures to implement its obligations under this Convention," and it specifies that these measures shall include "[p]rohibit[ing] natural and legal persons anywhere on [the party's] territory or in any other place under its jurisdiction as recognized by international law from undertaking any activity prohibited to a State Party under this Convention, including enacting penal legislation with respect to such activity." ${ }^{30}$ Elsewhere, the convention prohibits states parties from, among other things, developing, acquiring, or using chemical weapons, and it defines chemical weapons to include " $[t]$ oxic chemicals and their precursors, except where intended for purposes not prohibited under this Convention, as long as the types and quantities are consistent with such purposes." 31 The term "toxic chemicals" is in turn defined as "[a]ny chemical which through its chemical action on life processes can cause death, temporary incapacitation or permanent harm to humans or animals." 32 The phrase "purposes not prohibited under this Convention" is defined to include "[i]ndustrial, agricultural, research, medical, pharmaceutical or other peaceful purposes." 33

As part of its implementation of the convention, Congress enacted 18 U.S.C. $\$ 229$ (section 229), which makes it a federal crime for any person knowingly to "develop, produce, otherwise acquire, transfer directly or indirectly, receive, stockpile, retain, own, possess, or use, or threaten to use, any chemical weapon," and which defines "chemical weapon" in essentially the

${ }^{27}$ Id. at 460.

${ }^{28}$ Id. at 464; see also, e.g., United States v. Bass, 404 U.S. 336, 349 (1971) ("[U]nless Congress conveys its purpose clearly, it will not be deemed to have significantly changed the federal-state balance.").

${ }^{29}$ See supra note 2.

${ }^{30}$ Chemical Weapons Convention, supra note 2, Art. VII(1)(a).

${ }^{31}$ Id., Art. II(1).

${ }^{32}$ Id. Art. II(2).

${ }^{33}$ Id., Art. II (9). 
same way that it is defined in the convention. Thus, under section 229 , it is a crime to use, for nonpeaceful purposes, "any chemical which through its chemical action on life processes can cause death, temporary incapacitation or permanent harm to humans or animals." 34

In 2006, Carol Anne Bond, a microbiologist in Pennsylvania who worked for a chemical manufacturer, discovered that her friend had become pregnant and that the father of the child was Bond's husband. Seeking revenge, Bond initially engaged in various forms of harassment of the other woman, such as making threatening phone calls, for which she was prosecured under state law. Bond then stole an arsenic-based compound from her employer and purchased on the Internet a vial of a toxic chemical used in printing photographs and cleaning laboratory equipment, and she applied these chemicals to the other woman's house, car, and mailbox in an effort to cause her injury. The victim generally avoided contact with the chemicals, although in one instance she received a minor contact burn on her thumb. The victim eventually contacted federal authorities, and they proceeded to charge Bond with two counts of violating section 229. Bond entered into a conditional plea bargain that accepted guilt while preserving her right to appeal, and she was sentenced to six years in prison and five years of supervised release.

On appeal, Bond argued that the application of section 229 to her conduct exceeded the federal government's authority to regulate state and local matters, in violation of the Tenth Amendment to the Constitution. In 2011, the Supreme Court unanimously held that Bond had standing to raise this federalism argument. ${ }^{35}$ In an opinion written by Justice Kennedy, the Court reasoned that federalism protects not only the states, but also individual liberty, both by diffusing governmental authority and by enhancing the responsiveness and accountability of government decision making. ${ }^{36}$ In support of this proposition, the Court quoted from, among other authorities, Gregory v. Ashcroft. ${ }^{37}$ As a result, said the Court, "[a]n individual has a direct interest in objecting to laws that upset the constitutional balance between the National Government and the States when the enforcement of those laws causes injury that is concrete, particular, and redressable." 38

On remand, the U.S. Court of Appeals for the Third Circuit upheld Bond's conviction. ${ }^{39}$ The Third Circuit agreed with Bond that "treaty-implementing legislation ought not, by virtue of that status alone, stand immune from scrutiny under principles of federalism." 40 But the court concluded that the Chemical Weapons Convention addressed a subject matter that fell within the traditional scope of the national government's treaty power, and it quoted Missouri v. Holland for the proposition that, if a treaty is valid, "there can be no dispute about the validity" of a statute that implements the treaty. ${ }^{41}$ The court also rejected Bond's argument that section 229 should be interpreted not to cover a local poisoning case like the one at issue here. While noting that such a narrowing construction of the statute was "tempting, in light of the

${ }^{34} 18$ U.S.C. $\$ \$ 229(\mathrm{a})(1), 229 \mathrm{~F}(8)(\mathrm{A})(2012)$.

${ }^{35}$ See Bond v. United States, 131 S.Ct. 2355 (2011).

36 See, e.g., id. at 2364 ("By denying any one government complete jurisdiction over all the concerns of public life, federalism protects the liberty of the individual from arbitrary power.").

${ }^{37} 501$ U.S. 452 (1991); see supra text at notes 26-28.

${ }^{38} 131$ S.Ct. at 2364.

${ }^{39}$ Bond v. United States, 681 F.3d 149 (3d Cir. 2012).

${ }^{40} \mathrm{Id}$. at 151.

${ }^{41}$ Id. (quoting 252 U.S. at 432 ). 
challenges inherent in the Act's remarkably broad language," the court concluded that this construction was not possible in light of the statute's plain language. ${ }^{42}$

The Supreme Court unanimously voted to reverse. ${ }^{43}$ In an opinion written by Chief Justice Roberts, a majority of the Court reasoned that, despite its broad language, section 229 should not be interpreted to cover Bond's conduct. The Court began by emphasizing that, "[i]n our federal system, the National Government possesses only limited powers; the States and the people retain the remainder," and that, unlike the states, the national government does not have any general police power (p. 2086) ${ }^{44}$ Citing a variety of domestic federalism decisions, including Gregory v. Ashcroft, the Court said that, even for legislation implementing a treaty, it would presume that Congress does not intend to intrude on traditional areas of state authority, such as the prosecution of local crimes, absent a clear indication that Congress intended that result (p. 2089).

While acknowledging that section 229 could be read to cover Bond's conduct, the Court expressed concern that such a reading "would transform the statute from one whose core concerns are acts of war, assassination, and terrorism into a massive federal anti-poisoning regime that reaches the simplest of assaults" (pp. 2091-92). As an example of the alarmingly broad reach of the statute, the Court noted that "[a]ny parent would be guilty of a serious federal offense-possession of a chemical weapon-when, exasperated by the children's repeated failure to clean the goldfish tank, he considers poisoning the fish with a few drops of vinegar" (p. 2091). ${ }^{45}$ "If section 229 reached Bond's conduct," the Court reasoned, "it would mark a dramatic departure from [our] constitutional structure and a serious reallocation of criminal law enforcement authority between the Federal Government and the States. Absent a clear statement of that purpose, we will not presume Congress to have authorized such a stark intrusion into traditional state authority" (pp. 2093-94).

Despite the breadth of the statutory language, the Court concluded that it was ambiguous by virtue of

the improbably broad reach of the key statutory definition given the term-"chemical weapon"- being defined; the deeply serious consequences of adopting such a boundless reading; and the lack of any apparent need to do so in light of the context from which the statute arose-a treaty about chemical warfare and terrorism. (P. 2090)

Thus, instead of a literal reading of the statute, the Court applied what it described as the "natural meaning" of the term "chemical weapon," which it said involved a consideration of "both the particular chemicals that the defendant used and the circumstances in which she used them" (p. 2090). In concluding that Bond's conduct did not fall within that natural meaning, the Court noted that the chemicals at issue were "not of the sort that an ordinary person would associate with instruments of chemical warfare" (id.). In declining to interpret the statute to

${ }^{42} I d$. at 154.

${ }^{43}$ By this point, Bond was out of prison but still subject to court supervision.

${ }^{44}$ The page number references in the text are to volume 134 of the Supreme Court Reporter.

${ }^{45}$ Justice Alito had raised the hypotherical about pouring vinegar in a goldfish bowl during the first oral argument before the Court, in 2011. See Transcript of Oral Argument at 29-30; Bond v. United States, 134 S.Ct. 2077 (2014) (No. 09-1227), at http://www.supremecourt.gov/oral_arguments/argument_transcripts/09-1227.pdf. The hypothetical was discussed again during the second oral argument, and the attorney for the government attempted to dismiss it by noting that it "is not a real case." Transcript of Oral Argument at 36, id. (No. 12-158), at http://www.supremecourt.gov/oral_arguments/argument_transcripts/12-158_8m58.pdf. 
cover her conduct, the Court acknowledged that what Bond had done was "serious and unacceptable" but pointed out that such conduct was already addressed adequately by state laws, and that state authorities regularly applied these laws in similar poisoning cases. Although the Pennsylvania authorities in this case had prosecuted Bond only for a minor offense relating to harassment and had declined to prosecute her for assault, the Court noted that "the exercise of state officials' prosecutorial discretion [is] a valuable feature of our constitutional system" (p. 2092).

Justices Scalia, Thomas, and Alito concurred in the judgment. Unlike the majority, these Justices thought that the statute clearly covered Bond's conduct. They agreed with the decision to reverse, however, because they concluded that the application of the statute in this case was unconstitutional. Justice Thomas, writing for all three of these Justices, argued that the statute exceeded the proper subject matter scope of the treaty power because it addressed something that did not involve a matter of "international intercourse" (p. 2109, Thomas, J., concurring). While acknowledging that "the distinction between matters of international intercourse and matters of purely domestic regulation may not be obvious in all cases," Thomas noted that "this Court has long recognized that the Treaty Power is limited, and hypothetical difficulties in line-drawing are no reason to ignore a constitutional limit on federal power" (id., p. 2110). Justice Scalia, writing for himself and Justice Thomas, further argued that the statute exceeded Congress's authority under the Necessary and Proper Clause, which he construed as giving Congress the power to enact laws only to facilitate the making of treaties, not the implementation of treaties (p. 2099, Scalia, J., concurring). As a result, Scalia contended that " $[\mathrm{t}] \mathrm{o}$ legislate compliance with the United States' treaty obligations, Congress must rely upon its independent (though quite robust) Article I, $\$ 8$, powers" (id.).

\section{THE SIGNIFICANCE OF BOND}

Despite resolving the case on statutory rather than constitutional grounds, the decision in Bond is important. It extends a federalism-based clear statement requirement, which was originally developed by the Supreme Court in the context of purely domestic legislation, into the realm of treaty-implementing legislation. Although the Court noted that this case was "unusual" (p. 2093), the interpretive presumption applied by the Court may have implications for how other treaty-implementing legislation, especially criminal legislation, is construed. ${ }^{46}$ The Court's reasoning may also suggest that other federalism presumptions, such as the presumption against preemption of state law, apply in the treaty implementation context, and potentially in other foreign relations law contexts. ${ }^{47}$.

\footnotetext{
${ }^{46}$ Consider, for example, the Hostage Taking Act, 18 U.S.C. $\$ 1203$ (2012), which implements the International Convention Against the Taking of Hostages, a treaty ratified by the United States in 1984. By its terms, the Act appears to cover even local kidnappings that are designed to extract money from the victim's family, as long as an alien is involved. In decisions prior to Bond, lower courts had concluded that the Act applied in such local kidnapping cases, and that even if such an application of the Act exceeded Congress's normal legislative authority, it was valid under Missouri v. Holland. See United States v. Ferreira, 275 F.3d 1020 (11th Cir. 2001); United States v. Wang Kun Lue, 134 F.3d 79 (2d Cir. 1997).

${ }^{47}$ Cf. Crosby v. Nat'l Foreign Trade Council, 530 U.S. 363, 374 n.8 (2000) (noting, in a case involving a challenge to a state law that restricted trade with Burma, that "[w]e leave for another day a consideration in this context of a presumption against preemption").
} 
More generally, Bond is important because it highlights potential difficulties associated with converting multilateral regulatory treaties into domestic law. These treaties are often written in broad terms, both to achieve consensus among a large number of nations and to prevent nations from invoking technical loopholes to excuse problematic behavior. Although this method of drafting may be perfectly sensible for international relations, the resulting treaty language may not be well suited for direct incorporation into domestic legislation, especially criminal legislation aimed at private individuals. ${ }^{48}$ Among other things, this language may lack the specificity and precision normally thought desirable in the domestic context. Because the treaties are the product of negotiation among representatives from a variety of legal systems, they may also use terms and phrases in ways not typical of some national systems. Moreover, as the Bond case illustrates, such treaty language is unlikely to take account of the U.S. federal structure, which, among other things, generally leaves the prosecution of local crimes to the constituent states.

To be sure, if Congress attempts to be more precise in its implementing legislation, gaps may be created between the treaty and U.S. law that could result in less than full compliance with the treaty obligations. ${ }^{49}$ This is only a danger, however, not an inevitability. It is unlikely, for example, that other nations would have considered the United States to be in breach of the Chemical Weapons Convention if it had failed to punish Bond's conduct, let alone make it a federal criminal offense. As the majority noted in Bond, "There is no reason to think the sovereign nations that ratified the Convention were interested in anything like Bond's common law assault" (p. 2087)..$^{50}$ In any event, as the majority further observed, state law in the United States already prohibits Bond's conduct (p. 2092), and nothing in the convention requires the use of federal rather than state criminal law.

One potential virtue of the interpretive presumption applied by the Court in Bond, therefore, is that it might push Congress to deliberate more specifically, and to provide courts with more information, about how it wants a treaty implemented domestically. In a variety of other contexts, the Supreme Court has adopted interpretive canons that are designed to have these sorts of deliberation- and information-forcing effects. ${ }^{51}$ Another potential virtue of the interpretive presumption applied in Bond is that it may help avoid the need for judicially imposed limitations on the treaty power. The Supreme Court has never found a treaty to exceed the constitutional authority of the national government, and there are good reasons for the judiciary to be more cautious in this area than in the context of domestic legislation, in light of both limitations on judicial information and expertise and the potentially high stakes involved. But if the courts are going to leave the protection of state interests primarily to the political process, they need to be assured that those interests are actually being considered, as the Court emphasized in Gregory. If Congress simply copies broad treaty language into the criminal code, with

${ }^{48}$ See Curtis A. Bradley, Bond, Clear Statement Requirements, and Political Process, AJIL UNBOUND (June 3, 2014, 10:00 AM), at http://www.asil.org/blogs/; Kevin L. Cope, Lost in Translation: The Accidental Origins of Bond v. United States, 112 MICH. L. REV.: FIRST IMPRESSIONS 133 (2014).

${ }^{49}$ See Jean Galbraith, Silences in the Bond Case, OPINIO JURIS (June 2, 2014, 8:50 PM), at http://opiniojuris.org.

${ }^{50}$ In arguing the case before the Supreme Court, the solicitor general acknowledged that he did not "think anybody would say that ... whether or not Ms. Bond is prosecuted would give rise to an international incident." Transcript of Oral Argument at 46, Bond v. United States, No. 12-158, supra note 45.

${ }^{51}$ See generally EINER ELHAUGE, STATUTORY DEFAULT RULES: HOW TO INTERPRET UNCLEAR LEGISLATION (2008). 
the result that even pouring vinegar into a goldfish bowl is potentially a federal offense, it offers little assurance that the political process protections for federalism are functioning well.

That said, applying the federalism presumption has a potential drawback: it might render the scope of some treaty-implementing legislation too uncertain to be applied, at least in criminal prosecutions. The majority in Bond suggested vaguely, for example, that to be subject to prosecution under section 229 , the chemicals being used must be "of the sort that an ordinary person would associate with instruments of chemical warfare" (p. 2090). The majority also indicated that it would be important to consider whether the chemicals were being used in "combat," although it did not say that such a determination would always be required (pp. 2090-91). As Justice Scalia pointed out in his concurrence, the addition of these fairly indeterminate contextual considerations, which are not themselves set forth in the statute or defined by Congress, may make it difficult for the statute to provide sufficient notice to potential defendants of what conduct the statute is criminalizing (p. 2097, Scalia, J., concurring). Of course, Congress could address the problem by amending the statute to make it more precise.

Finally, although the majority in Bond declined to address the constitutional issues concerning the scope of the treaty power, the concurring opinions are likely to reinvigorate debates about those issues. In particular, the express endorsement by three Justices of a subject matter limitation on the treaty power-contrary to the position reflected in the American Law Institute's Restatement (Third) of Foreign Relations Law-will raise new questions about whether certain types of agreements fall outside the national government's authority. These questions will probably be most prominent with respect to human rights treaties, which, although they address matters of significant concern to the international community, do not involve traditional cross-border or reciprocal commitments among nations. Some private international law treaties, concerning topics such as family law, commercial law, and judicial procedure, may also present federalism questions in light of the extensive overlap of these treaties with matters traditionally regulated by state law. ${ }^{52}$ At the very least, the Bond case may cause the national government to be even more reluctant to use treaties to expand Congress's domestic regulatory authority, since such use could lead to additional judicial scrutiny of the appropriate subjects of treaty making.

Some commentators seek to draw inferences from what a majority of the Court in Bond did not say. ${ }^{53}$ Such speculations, in this author's opinion, provide little basis for predicting the outcome of future cases. In any event, the silences in the majority opinion point in opposite directions. On the one hand, the majority did not repudiate Holland or endorse any particular federalism limitations, including the limitations suggested in the concurrences. On the other hand, the majority did not take the opportunity to reaffirm Holland or disavow federalism limitations on the treaty power. Just as a cigar is sometimes just a cigar, sometimes constitutional avoidance is simply constitutional avoidance. What we do know is that the Supreme Court

\footnotetext{
${ }^{52}$ International efforts to address private international law topics have long implicated federalism concerns within the United States. See, e.g., Kurt H. Nadelmann, Ignored State Interests: The Federal Government and International Efforts to Unify Rules of Private Law, 102 U. PA. L. REV. 323 (1954).

${ }^{53}$ See, e.g., David Golove \& Marty Lederman, Stepping Back from the Precipice in Bond, JUST SECURTY (June 3, 2014, 5:40 PM), at http://justsecurity.org.
} 
took federalism seriously in this context, and that it held 9-0 that the treaty-implementing legislation could not be used to prosecute Carol Anne Bond.

CURTIS A. BRADLEY

Of the Board of Editors

International Convention for the Regulation of Whaling — moratorium in the Southern Ocean Sanctuaryscientific research - use of expert scientific evidence-objective assessment of reasonable exceptions

WHALING IN THE ANTARCTIC (Australia v. Japan: New Zealand Intervening). At http://www.icjcij.org.

International Court of Justice, March 31, 2014.

The International Court of Justice (ICJ or Court) decided, by a 12-4 majority, ${ }^{1}$ that the whaling program conducted by Japan in the Antarctic Ocean was in breach of its obligations under the International Convention for the Regulation of Whaling (ICRW or Convention). ${ }^{2}$ Relying in substantial part on expert testimony submitted by the parties, the Court found that the activities conducted under the program were not "for purposes of scientific research" as required by the treaty (paras. 227, 247(2)). While the judgment provoked four written dissents (as well as six other separate opinions and one declaration), it represents an important, if somewhat conservative, precedent in the Court's consideration of international environmental issues.

The ICRW and its governing body the International Whaling Commission (Commission) were created in 1946 "to provide for the proper conservation of whale stocks and thus make possible the orderly development of the whaling industry." ${ }^{3}$ The Commission is authorized to set limits on commercial and aboriginal whaling. In 1982, it imposed a commercial whaling moratorium by setting the quota levels for catches of all whale species at zero in its binding Schedule. ${ }^{4}$ Nevertheless, ICRW Article VIII(1) allows a state party to "grant to any of its nationals a special permit authorizing that national to kill, take, and treat whales for purposes of scientific research subject to such restrictions as to number and subject to such other conditions as the Contracting Government thinks fit."

Pursuant to that authority, Japan instituted a program in 2005 to permit scientific whaling that included lethal "sampling" of various species (fin, humpback, and minke whales) in the Southern Ocean Sanctuary (the Japanese Whaling Research Program under Special Permit in the Antarctic, Phase II, known as "JARPA II"). Before the Court, Australia challenged the legitimacy of that program, contending that because it allowed the taking of whales in large numbers, it amounted to a thinly veiled attempt to sustain a whaling industry in breach of the

${ }^{1}$ Whaling in the Antarctic (Austl. v. Japan: N.Z. Intervening) (Int'lCt. Justice Mar. 31, 2014) [hereinafter Judgment]. Judgments and documents of the Court cited herein are available at its website, http://www.icj-cij.org.

${ }^{2}$ International Convention for the Regulation of Whaling (with Annexed Schedule), Dec. 2, 1946, 62 Stat. 1716, 161 UNTS 72 (entered into force Nov. 10, 1948).

${ }^{3} I d$. pmbl.

${ }^{4} I d$., Schedule, para. 10(d), as amended July 2012, at http://iwc.int. 